\title{
DAMPAK MEDIA PEMBELAJARAN ONLINE PADA PENDIDIKAN ISLAM MTS AL MUHAJIRIN MANADO DALAM PERSPEKTIF PSIKOLOGI ANAK DI ERA COVID-19
}

\author{
Nur'ain Pakaya, Faudzan Azhar Kida, Wirahayu Atas \\ Institut Agama Islam Negeri Manado \\ Email : nurainpakaya212@gmail.com
}

\begin{abstract}
This study aims to determine the impact of online learning on Islamic education at Madrasah Al Muhajirin Manado in the covid-19 era. This study uses qualitative methods by collecting observation and interview data. The result is the online learning is less effective because several subjects are difficult to understand since every child has psychological and background differences when viewed in terms of student attitudes or behavior. In online learning, the teacher only provides material and assignments, so that the process that occurs is only teaching, while there is no moral education. Besides, several students cannot afford the internet quota to do online learning. So, the conclusion of this research is that method isn't effective.
\end{abstract}

Keywords: Online Learning, Covid-19

\begin{abstract}
ABSTRAK
Penelitian ini bertujuan untuk mengetahui dampak pembelajaran online pada pendidikan Islam di Madrasah Al Muhajirin Manado pada era covid-19. Penelitian ini menggunakan metode kualitatif dengan cara pengumpulan data observasi dan wawancara. Hasil penelitian menunjukan bahwa pembelajaran online kurang efektif, karena ada beberapa mata pelajaran yang sulit dipahami apalagi melihat setiap anak memiliki latar belakang dan psikologis yang berbeda-beda apabila dilihat dari segi sikap atau perilaku siswa. Dalam pembelajaran online, guru hanya memberikan materi dan tugas, sehingga proses yang terjadi hanya pengajaran saja, sedangkan pendidikan akhlak tidak ada. Selain itu, dari segi ekonomi keluarga, dimana siswa yang tidak mampu membeli kuota internet untuk belajar. Sehingga dapat disimpulkan bahwa metode ini tidak efektif.
\end{abstract}

Kata Kunci: Pembelajaran Online, Covid-19

\section{PENDAHULUAN}

Pada awal tahun 2020 dunia digemparkan dengan penemuan virus baru yaitu yang disebut dengan virus covid-19 atau virus corona atau dengan kata lain dapat juga disebut dengan Severe Acute Respiratory Syndrome Coronavirus 2 (SARS-CoV-2). Virus ini tentunya sangat berbahaya dan mematikan. Penyebarannya yang begitu luas membuat pemerintah harus bertindak lebih cepat agar tidak menelan lebih banyak korban. Sejak itulah Menteri Pendidikan mengambil kebijakan dengan menggunakan metode sekolah daring (dalam jaringan). Langkah ini diambil guna mencegah perluasan penularan virus corona. Tentunya, metode sekolah daring ini memiliki dampak positif 
dan negatif bagi dunia pendidikan terutama bagi guru-guru Pendidikan Agama Islam (PAI). Karena kasus ini adalah hal baru dalam dunia pendidikan yang jelas belum mempunyai persiapan yang begitu matang. Baik dari segi persipan kurikulum dan lainnya. Begitupun halnya dengan guru PAI yang merasakan dampak negatif dan positif dari pembelajaran berbasis online selama masa pandemi Covid-19.

Dampak positif dari media pembelajaran online bagi guru PAI adalah guru dituntut untuk lebih kretaif dalam menyiapkan media online yang menarik sehingga materi yang akan disampaikan mudah diterima oleh peserta didik. Selain itu tentunya media online ini akan menghemat waktu dan biaya para guru dalam hal mempersiapkan rmedia pembelajaran. Kendati demikian, ada beberapa dampak negatif dari media pempelajaran berbasis online dalam proses kegiatan belajar mengajar di masa Pandemi Covid-19. Adapun dampak negatif yang dirasakan oleh guru PAI tersebut adalah bahwa media pembelajaran berbasis online ini tidak begitu efektif dalam penerapannya selama proses kegiatan belajar mengajar berlangsung. Hal ini tampak banyaknya keluhan peserta didik yang kurang memahami materi yang disampaikan oleh guru tersebut. Selain itu, tidak sedikit peserta didik yang mengeluh karena jaringan yang susah diakses menyebabkan media pembelajaran berbasis online ini tidak efektif. Selain itu, banyak juga peserta didik yang mengharapkan pembelajaran tatap muka secara langsung. Karena pelajaran dengan tatap muka langsung memudahkan peserta didik untuk memahami materi yang disampaikan oleh guru tersebut. Tidak hanya peserta didik yang merasakan dampak negatif dari media pembelajaran yang berbasis online ini. Tetapi pendidik juga merasakan hal yang serupa dimana para pendidik mengeluh bahwa mereka juga kesulitan dalam memberikan materi.

Dalam Undang-Undang No. 20 Tahun 2003 tentang Sistem Pendidikan Nasional dinyatakan bahwa pendidikan nasional bertujuan untuk berkembangnya potensi peserta didik agar menjadi manusia yang beriman dan bertaqwa kepada Tuhan Yang Maha Esa, berakhlak mulia, sehat, berilmu, cakap, kreatif, mandiri, dan menjadi warga negara yang demokratis serta bertanggung jawab.

Pemaparan di atas dapat dirumuskan bahwa pendidikan madrasah merupakan bagian integral dari sistem pendidikan nasional. Pendidikan madrasah yang di dalamnya terdapat Pendidikan Agama Islam disemua jalur dan jenjang pendidikan menjadi penentu terhadap pencapaian tujuan pendidikan nasional di 
Indonesia. Karena salah satu fungsi pendidikan agama adalah untuk mewujudkan manusia yang yang beriman dan bertakwa kepada Tuhan Yang Maha Esa. Usaha mewujudkan manusia yang beriman dan bertakwa tidak dapat dilakukan kecuali melalui pendidikan agama.

Pendidikan agama wajib diberikan disemua jalur dan jenjang pendidikan. Salah satu jalur dan jenjang pendidikan tersebut adalah jenjang pendidikan dasar, dalam hal ini terdiri dari satuan pendidikan dasar dan sekolah menengah pertama.

Dalam Garis-Garis Besar Program Pengajaran (GBPP) Pendidikan Agama Islam pada Sekolah Dasar yang sering disebut dengan kurikulum 1994, dinyatakan tentang tujuan pendidikan madrasah yaitu memberikan kemampuan dasar kepada siswa tentang agama Islam untuk mengembangkan kehidupan beragama sehingga menjadi manusia muslim yang beriman dan bertaqwa kepada Allah SWT.

\section{METODE PENELITIAN}

Penelitian ini dilakukan dengan menggunakan metode kualitatif. Metode ini digunakan agar dapat menghimpun informasi-informasi baru. Observasi partisipatif, wawancara mendalam serta studi dokumentasi dilakukan di lokasi MTs Al Muhajirin Manado Penelitian ini berlangsung pada tanggal 13 November 2020. Pengumpulan data dilakukan dengan mengombinasikan teknik wawancara idividual serta studi dokumen literatur. Narasumber penelitian ini mencakup Siswa- Siswi MTs Al Muhajirin Manado.

\section{PEMBAHASAN}

Siswa mendapatkan tugas yang harus diselesaikan, $87 \%$ siswa memperoleh manfaat dari penyampaian materi oleh guru. Namun hanya $45 \%$ siswa yang mengerjakannya karena faktor malas. Hal ini diungkapkan oleh salah satu siswa kelas VIII MTs Al Muhajirin mengenai pembelajaran Online.

"Alif nimau download itu aplikasi karna alif pe Ram di hp ndk pas salah satunya aplikasi buku online dan zoom beserta kuota yang tiap hari takuras." (Salah satu wawancara dari siswa VIII Mts Muh. Alif Algifahri).

"Pembelajaran online enak, di rumah terus tapi ada juga rasa ingin tatap muka karena ada beberapa mata pelajaran yang susah untuk dipahami kalau online. Salah satunya mata pelajaran Bahasa Arab, matematika, fiqih, Al Quran Hadis. Jika mata pelajaran susah di pahami maka alif akan jadi malas mengerjakan tugas." (Salah satu wawancara dari siswa VIII MTs Muh. Alif Algifahri). 
Jika dilihat disini guru hanya memberikan materi saja. Siswa hanya mendapatkan pengajaran tanpa pendidikan terutama dalam pendidikan adab.

Hasil observasi dan wawancara pada siswa tersebut, dapat disimpulkan bahwa dampak negatif pendidikan saat Covid-19:

1. Daerah yang minim akses internet mengalami hambatan kegiatan belajar dan mengajar.

2. Minimnya bukti kolaborasi antar negara dalam kondisi ini. Seperti Tiongkok dalam penanganan sistem pendidikan di masa pandemi.

3. Dorongan yang dipaksakan kepada para pendidik untuk mengajar dalam sistem pendidikan yang belum begitu siap.

4. Sistem pembelajaran yang kolaboratif dan kooperatif begitu terbatas seperti kelas seni, musik, teater dan lain-lain.

5. Pembelajar yang termotivasi secara intrinsik relatif tidak merasakan pengaruh tanpa kehadiran pembimbing. Namun, bagi mereka yang suka belajar secara otodidak lebih suka mandiri dan belajar sendiri.

6. Adanya kekhawatiran tentang peningkatan pembelajaran di depan layar seperti komputer, handphone, pada peserta didik sementara para guru perlu melayani aktivitas-aktivitas secara offline.
7. Seringkali seluruh anggota keluarga berada di rumah sedangkan orang tua bekerja di luar rumah.

8. Tidak adanya kejelasan tentang praktik terbaik untuk jangka umur yang berbeda dalam perkembangan mereka di dalam sistem homeschooling. Maka dari itu muncullah pertanyaan bagaimana kita melayani murid-murid dengan kesulitan belajar dan kebutuhan khusus.

Selain dampak negatif, terdapat pula dampak positif dan tantangan pembelajaran pada masa Covid-19 yaitu:

1. Guru dan wali murid memiliki hubungan yang lebih kuat dan dekat.

2. Pendidik mendapatkan kesempatan yang lebih luas dalam mengembangkan inisiatif yang kreatif dalam mendidik ketika tidak bertemu secara fisik.

3. Banyaknya bukti bahwa para guru lebih aktif berkolaborasi dengan guru-guru lain, institusi, bahkan sampai menyentuh kancah lokal yang kecil.

4. Adanya kesempatan yang tidak paralel untuk bekerja sama, kreatif solusi, dan kemauan untuk belajar dari sesama. Karena guru, wali murid, dan murid berbagi dari pengalaman dan keadaan yang sama-sama dialami.

5. Banyak dari lembaga pendidikan formal maupun non-formal, profit maupun nonprofit menawarkan alat dan program 
juga solusi untuk mendukung para pendidik, guru, dan murid.

6. Pembelajaran online menyediakan kesempatan untuk belajar dengan cara yang baru dan kembali membuat kita berpikir tentang pandangan kita terhadap sistem pendidikan sebelumnya.

7. Murid menjadi penanggung jawab akan dirinya sendiri untuk mengeksplorasi hal-hal baru dan pengalaman yang sebelumnya belum pernah didapat. Juga menemukan dan mendalami bidang yang mereka minati.

8. Adanya kesempatan memikirkan dan mendalami juga mengintrospeksi seperti apakah sistem pendidikan yang selayaknya berjalan.

\section{PENUTUP}

Pembelajaran daring (dalam jaringan), online atau pembelajaran jarak jauh sendiri bertujuan untuk memenuhi standar pendidikan dengan pemanfaatan teknologi informasi dengan menggunakan perangkat komputer atau gadget yang saling terhubung antara siswa dan guru, mahasiswa dengan dosen, sehingga melalui pemanfaatan teknologi tersebut proses belajar mengajar bisa tetap dilaksanakan dengan baik. Pemanfaatan teknologi informasi diharapkan mampu mengatasi proses belajar mengajar agar tetap berjalan dengan baik meskipun berada pada masa pandemi virus Covid-19. hal ini dimungkinkan bisa terlaksana dengan baik karena masyarakat Indonesia saat ini mayoritas sudah menggunakan internet hal ini sesuai dengan penelitian WE ARE SOCIAL, "Digital Report 2020" yang dirilis pada akhir Januari 2020 menyatakan hampir 64 persen penduduk Indonesia sudah terkoneksi dengan jaringan internet, jumlah pengguna internet di Indonesia sudah mencapai 175,4 juta orang dari total jumlah penduduk Indonesia yang berjumlah sekitar 272,1 juta dan dibanding tahun 2019 lalu, jumlah pengguna internet di Indonesia meningkat sekitar 17 persen atau 25 juta pengguna. Tapi dengan pembelajaran online sangat berpengaruh pada sikap atau perilaku siswa.

\section{DAFTAR PUSTAKA}

Sawa, Mr. K. (2013). Sistem Pendidikan Madrasah: Studi Atas Ma'had Darul Maarif Di Patani Selatan Thailand. Skripsi. Universitas Islam Negeri Walisongo Semarang.

Ulfa, M. (2010). Konsep Pendidikan Islam Menurut Syed Muhammad Al Naquib Al Attas. Skripsi. Fakultas Agama Islam Universitas Muhammadiyyah Surakarta.

Widakdo, J., Gibraltar, K., dan Fananie, B. (2020). Dampak Pembelajaran Online Dalam Sistem Pendidikan Indonesia Pasca Pandemi COVID-19. White Paper Perhimpunan Pelajar Indonesia Se-Dunia, hal 2. 